\title{
Seasonal variation in the effect of dietary RNA on criteria of energy homoeostasis in the rat
}

\author{
BY D. J. HEAF*, D. G. PEERS $†$ AND J. I. DAVIES \\ Department of Biochemistry and Soil Science, University College of North Wales, \\ Bangor, Gwynedd, LL57 $2 U W$
}

Received 2 September 1977 - Accepted 13 July 1978)

1. RNA was administered to rats as part of a meal while standardizing food intake and minimizing the effects of psychological stress and diurnal metabolic rhythms. It was demonstrated that circulating levels of glucose and free fatty acids (FFA) in the animals, which were deprived of food for $48 \mathrm{~h}$, were responsive to orally administered caffeine.

2. Inclusion of RNA in the diet slightly but consistently reduced the normal postprandial hyperglycaemia. Its effect on plasma FFA was variable although statistically significant in some experiments. The differences between RNA- and control-fed animals were not attributable to differences in the rate of passage of digesta along the gastrointestinal tract.

3. Evidence was obtained that the variability in the FFA response was related to a seasonally-dependent change in the state of the animals. The synchronizer ('Zeitgeber') responsible for this change was not identified and no satisfactory way of suppressing its effect was found.

4. The present findings, taken in conjunction with those of previous workers, suggest that there is a seasonal influence on the sympathetic nervous system manifesting itself as a variable susceptibility to arousal or excitation.

The testing required before 'single-cell' protein (SCP) can be introduced into the diet of higher animals is broadly that appropriate for new drugs and food additives, especially drugs intended for long-term use. The normal precaution of administering the agent under investigation at levels which are in excess of those intended for routine use leads to special difficulties in the instance of SCP. Since, as a source of protein, it can become a major component of well-balanced foodstuffs, test diets will almost inevitably have certain physical and chemical characteristics which cannot be compensated in control diets. However, the heterogeneity of SCP allows this problem to be partially overcome by testing individual components of the material (cf. Friedman et al. 1971).

Unless special precautions are taken to remove it, nucleic acid (particularly RNA) represents one of the major components of SCP. Although this fraction has been the subject of special attention (Kihlberg, 1972), studies have for the most part been devoted to the problem of excess uric acid production (Waslien et al. 1968; Bowering et al. 1970). We have shown that a number of other disturbances occur in the composition of the body fluids of RNA-fed rats, including a marked increase in uracil levels (Heaf \& Davies, 1976). These findings suggest that investigations into the RNA fraction of SCP should be more broadly based.

In an initial toxicological study (Peers et al. 1973; Peers, 1974), rats were maintained on diets containing $74 \mathrm{~g} / \mathrm{kg}$ RNA for up to $\mathrm{I} 8 \mathrm{~d}$ with no apparent ill-effects in respect of live weight gain, food and water intake, liver weight,"plasma glutamic-oxaloacetic transaminase (EC 2.6.I.I) and glutamic-pyruvic transaminase (EC 2.6.1.2), or liver and kidney histology.

Attention was therefore turned to more sensitive indicators of metabolic activity in order to anticipate disturbances of body function which are of interest chiefly in the longer term.

* Present address: Department of Biochemistry, University of Liverpool, Liverpool L69 3BX.

$\uparrow$ Present address: School of Agriculture, University of Edinburgh, West Mains Rd, Edinburgh. 
Table I. Ingredients and chemical composition $(\mathrm{g} / \mathrm{kg})$ of experimental diets

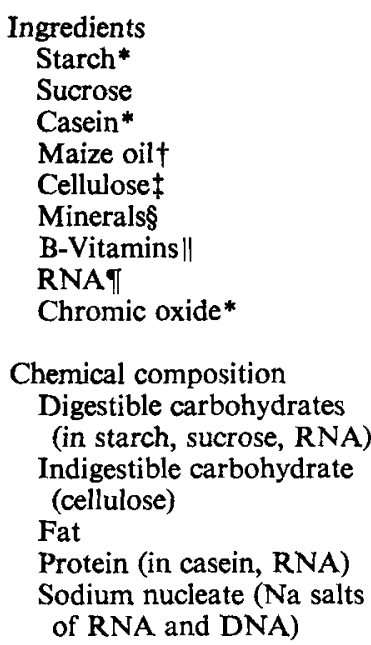

\begin{tabular}{cr} 
Control & RNA \\
290 & 290 \\
230 & 230 \\
150 & 135 \\
100 & 100 \\
150 & 50 \\
40 & 40 \\
40 & 40 \\
\hline 0.1 & 115 \\
& 0.1 \\
& \\
520 & 554 \\
150 & \\
100 & 50 \\
150 & 150 \\
- & $91 \cdot 3$
\end{tabular}

* Purchased from British Drug Houses Ltd, Poole, Dorset.

† Obtained from Boots Pure Drugs Ltd, Nottingham. It was supplemented with a mixture of vitamins A and D (Adexolin; Glaxo Ltd, Greenford, Middlesex, supplying $15.8 \mathrm{mg}$ retinol and $0.667 \mathrm{mg}$ ergocalciferol/ $\mathrm{kg}$ diet).

$\ddagger$ Fibrous (CF I I) obtained from Whatman Biochemicals Ltd, Maidstone, Kent.

$\S$ Formulated according to Cuthbertson (1957). Menaphthone (Acetomenaphthone tablets; Boots Pure Drug Co. Ltd,) was added to provide $1 \mathrm{mg} / \mathrm{kg}$ diet.

1| Dried brewers' yeast, purchased from Trent Yeast Extract Co. Ltd, Burton-on-Trent, Staffs.

T Extracted from torula yeast (Type II-s; Sigma London Chemical Co. Ltd, London) and contained $(\mathrm{g} / \mathrm{kg})$ : RNA 740, DNA 24, sodium ions 30, protein 135 (Biuret method; Layne, I957); the remainder was accounted for by moisture. The nucleic acid fraction contained ( $\mathrm{mol} / \mathrm{mol}$ nucleotide) adenine $0 \cdot 270$, guanine 0.279 , cytosine 0.209 , uracil 0.240. The amino acid composition (mg/g RNA preparation; Thomas, I970) was aspartic acid $15 \cdot 9$, threonine $7 \cdot 0$, serine $I I \cdot I$, glutamic acid $25 \cdot I$, glycine $11 \cdot 2$, alanine $9 \cdot 1$, cystine $2 \cdot 2$, valine $4 \cdot 0$, isoleucine $3 \cdot 2$, leucine $7 \cdot 5$, tyrosine $5 \cdot 2$, phenylalanine $4 \cdot 3$, histidine $4 \cdot 4$, lysine $8 \cdot 8$, arginine $6 \cdot 2$ (Tryptophan and methionine were not determined because of their instability under the conditions used for acid-hydrolysis; proline values were not quoted because the colorimeter was insensitive to its ninhydrin derivative).

In determining the effect of the RNA component of a foodstuff on glucose and free fatty acids (FFA) in blood, an experimental design was required which would allow for its oral administration as part of a meal. The necessary precautions included standardization of food intake, accommodation of diurnal metabolic rhythms and control of psychological stress. In spite of dealing with these problems, difficulties were encountered with a longerterm (apparently circannual) metabolic rhythm. A considerable portion of our report concerns a seasonal influence on the effect of dietary RNA on plasma FFA of rats bred and housed under standardized lighting.

\section{MATERIALS AND METHODS}

Animals. Albino, male Wistar rats (Charles River UK Ltd, Margate, Kent) were used in all experiments. After shipment, which was completed within less than $24 \mathrm{~h}$, housing conditions almost identical to those quoted by the supplier were resumed consisting of standardized artificial lighting (daylight excluded) between 07.00 hours and 19.00 hours in a ventilated room with free access to food (Diet $4 \mathrm{IB}$, Oxoid Ltd, Bewdley, Oxon) and water. 
The temperature was maintained thermostatically at $21^{\circ}$, but there was no air-conditioning. After a $14 \mathrm{~d}$ acclimatization period, randomly selected animals were individually housed in stainless steel metabolism cages. The latter were designed in such a way that food presentation did not require entry into the cage. Portions of the diet were weighed into stainless steel pots and inserted into devices which could be slid into a position which made the food accessible. The cages prevented the retention of urine and faeces but were not specially designed to eliminate coprophagy.

The body-weight of rats at the beginning of different experiments ranged from $150-270 \mathrm{~g}$, but was restricted to very narrow limits within' individual trials (see tables and figures).

Diets. A single batch of a commercial sodium ribonucleate preparation (Type IIS, approximately $850 \mathrm{mg}$ sodium ribonucleate/g; Sigma London Chemical Co., Ltd, London) from torula yeast was used throughout. This preparation was found on analysis to contain (mg/g): free RNA, 740; free DNA, 24; sodium, 30; protein, 135. The nucleic acid fraction contained ( $\mathrm{mol} / \mathrm{mol}$ nucleotide): adenine, 0.270; cytosine, 0.209; guanine, 0.279; uracil, 0.240 : torula yeast RNA was included in the diet by substitution for part of the cellulose component of a well-balanced 'control diet' to provide $86 \mathrm{~g} \mathrm{RNA} / \mathrm{kg}$ (9I.3 g sodium nucleate $/ \mathrm{kg}$ ) by analysis in the 'RNA diet' as shown in Table $\mathrm{I}$.

The casein content of the RNA diet was adjusted to compensate for the small amount of protein present in the torula-yeast-RNA preparation (for details, see Heaf \& Davies, 1976). The inert marker chromic oxide was included in both the RNA and control diets for assessment of digesta flow along the gastrointestinal tract.

Food presentation and RNA administration. In experiments, it was necessary to ensure that the pattern of food intake and its total consumption were both carefully controlled. The method used was first to fast the rats for $48 \mathrm{~h}$. Then portions of either the control or RNA diet were weighed into stainless steel pots and mixed to a stiff paste with water before presentation. The amount of food given (generally $10 \mathrm{~g}$; see individual tables and figures) had been shown previously to be sufficient to satisfy rats of their weight under normal meal-feeding conditions and was therefore rapidly consumed by the fasted animals.

Caffeine administration. Rats which were given caffeine (BDH Ltd, Poole, Dorset) each received a $50 \mathrm{mg}$ dose suspended in $\mathrm{I} \mathrm{ml}$ of a $2 \% \mathrm{w} / \mathrm{v}$ solution of carboxymethyl cellulose (CMC solution; $20 \mathrm{~g} / \mathrm{l}$ ). The mixture was introduced through a tube into the stomach of rats which were lightly-anaesthetized with diethyl ether.

Sampling procedures. Rats were killed by minimal exposure to diethyl ether and samples of blood taken from the heart using heparinized syringes. Plasma was separated from whole blood and stored at $-20^{\circ}$ until analysed. One experiment was performed in which the effect of this method on subsequent blood constituent analysis was compared with that of the more rapid decapitation and exsanguination from the neck.

After completion of blood sampling, segments of digestive tract were removed for $\mathrm{Cr}_{2} \mathrm{O}_{3}$ analysis (Heaf \& Davies, 1976).

Analytical procedures. In analysing composite FFA results from more than one experiment, analysis of variance was performed on values transformed to their natural logarithms to accommodate the positive relationship which existed between mean values and their variances (Snedecor \& Cochran, 1967). In these situations, it was generally necessary to accommodate variations between experiments in the nos. of animals/group. The method used was that recommended by Snedecor \& Cochran (1967) for handling unequal cell frequencies.

\section{RESULTS}

Comparison of blood sampling procedures. Twelve rats were fasted for $48 \mathrm{~h}$ and then bled by one of two procedures alternately. The blood from six rats killed by diethyl ether exposure 
Table 2. Comparison of two methods for collecting blood from 48 h-fasted rats in their effect on the glucose, free fatty acid (FFA) and lactate analysis of the samples obtained

(Mean values with their standard errors for individual determinations on blood from six rats*)

\begin{tabular}{|c|c|c|c|c|c|c|c|c|}
\hline \multirow{2}{*}{$\begin{array}{c}\text { Method of killing } \\
\text { exposure }\end{array}$} & \multicolumn{2}{|c|}{$\begin{array}{l}\text { Packed cell } \\
\text { volume }\end{array}$} & \multicolumn{2}{|c|}{$\begin{array}{c}\text { Plasma } \\
\text { glucose } \\
(\mathrm{mmol} / \mathrm{l})\end{array}$} & \multicolumn{2}{|c|}{$\begin{array}{l}\text { Plasma FFA } \\
(\mu \mathrm{mol} / \mathrm{l})\end{array}$} & \multicolumn{2}{|c|}{$\begin{array}{l}\text { Plasma } \\
\text { lactate } \\
(\mathrm{mmol} / \mathrm{l})\end{array}$} \\
\hline & Mean & SE & Mean & $\mathrm{SE}$ & Mean & SE & Mean & SE \\
\hline Decapitation & 0.50 & 0.016 & $5 \cdot 5$ & 0.30 & 860 & 21 & $3 \cdot 18$ & 0.86 \\
\hline $\begin{array}{l}\text { Diethyl ether } \\
\text { exposure }\end{array}$ & 0.52 & 0.004 & 6.5 & 0.23 & 902 & $7 \mathrm{I}$ & $3 \cdot 52$ & 0.70 \\
\hline
\end{tabular}

Statistical significance of difference (Student's $t$ test):

NS, not significant.

NS $\quad P<0.05$

NS

NS

* Body-weight before fasting 250-300 $\mathrm{g}$.

Table 3. The effect of ingestion of an RNA-containing diet ( $2 \mathrm{~g} /$ rat per $d, \mathrm{I} \cdot 04 \mathrm{~g} R N A$ ) by rats over $7 d$ on the glucose and free fatty acid (FFA) composition of their blood in January 1970

(Mean values with their standard errors for individual analysis of blood from three rats*)

\begin{tabular}{|c|c|c|c|c|c|c|c|c|}
\hline \multirow{3}{*}{$\begin{array}{l}\text { Sampling interval } \\
(24 \mathrm{~h} \text { period) }\end{array}$} & \multicolumn{4}{|c|}{ Plasma glucose (mmol/l) } & \multicolumn{4}{|c|}{ Plasma FFA $(\mu \mathrm{mol} / \mathrm{l})$} \\
\hline & \multicolumn{2}{|c|}{ Control diet } & \multicolumn{2}{|c|}{ RNA diet } & \multicolumn{2}{|c|}{ Control diet } & \multicolumn{2}{|c|}{ RNA diet } \\
\hline & Mean & SE & Mean & $\mathbf{S E}$ & Mean & SE & Mean & SE \\
\hline $\mathbf{I}$ & 8.67 & 0.12 & $8 \cdot I I$ & 0.13 & 473 & 7 & 857 & 99 \\
\hline 2 & $8 \cdot 50$ & 0.12 & $8 \cdot \mathrm{II}$ & 0.13 & 380 & 45 & 682 & 8 \\
\hline 4 & $8 \cdot 28$ & 0.31 & $8 \cdot 44$ & 0.06 & 517 & 78 & 667 & 33 \\
\hline 7 & $8 \cdot 28$ & 0.27 & 7.94 & 0.13 & 297 & 32 & 582 & 59 \\
\hline
\end{tabular}

Statistical significance of differences (analysis of variance):

$\operatorname{Diet}(\mathrm{D})$

Time (T)

$\mathrm{D} \times \mathrm{T}$ interaction

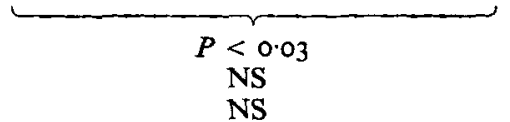

NS, not significant.

* Body-weight before fasting 145-155 g.

was drawn by cardiac puncture whereas that of the animals killed by decapitation was obtained by exsanguination from the neck. With cardiac puncture, it took up to 3 min from the time of cage-opening to cornplete the blood sampling, whereas with decapitation it took less than $2 \mathrm{~min}$. Table 2 shows that, whereas mean values for packed cell volume (recognized to be high in fasted animals; Kutscher, 197I), plasma FFA and lactate were unaffected by the method of killing, mean glucose concentrations were $17 \%$ higher in the group killed by diethyl ether exposure compared with the group killed by decapitation.

7 d feeding trial with $R N A$. Twenty-four rats were randomly divided into two groups and fasted for $4^{8} \mathrm{~h}$. Refeeding with $12 \mathrm{~g}$ of either the control or RNA diet was then commenced at 19.00 hours (the beginning of the dark period). After a further $\mathrm{I} 6 \mathrm{~h}$, three rats from each dietary group were removed for bleeding (cardiac puncture). The feeding pattern was repeated on each successive evening for the surviving rats which became progressively 
reduced in number as further groups were removed for bleeding on the second, fourth and seventh $24 \mathrm{~h}$ period after the fast.

Rats appeared to consume the RNA diets without hesitation and without any accompanying digestive disturbances such as diarrhoea. As shown in Table 3, postprandial plasma glucose concentrations were slightly lowered $(P<0.03)$ in rats fed on the RNA diet whereas plasma FFA were markedly increased $(P<0.001)$. These changes, which were apparent as early as the first day of refeeding, persisted slightly diminished in magnitude for the $7 \mathrm{~d}$ of the trial.

Effects of caffeine administration From the result of the $7 \mathrm{~d}$ feeding trial it was clear that the differences between rats fed on the RNA diet and the control diet could be detected within the first $24 \mathrm{~h}$ of refeeding.

Therefore, subsequent experiments were designed to investigate the responses obtained to one post-fast meal.

Fasting is known to affect the responsiveness of plasma FFA and glucose to many drugs (Bizzi \& Garattini, I966). In order to assess the standardized experimental design adopted, preliminary studies were undertaken in which caffeine was used as a reference substance.

Rats were reluctant to consume food consisting of the control diet supplemented with caffeine $(5-10 \mathrm{~g} / \mathrm{kg}$ diet $)$. Therefore, animals which had been fasted for $48 \mathrm{~h}$ were all given Io $g$ of control diet at the beginning of the dark period (19.00 hours). After $3 \mathrm{~h}$ (when the food provided was completely ingested), one group of animals was bled and the remainder given by stomach tube either the caffeine $(50 \mathrm{mg} / \mathrm{rat})$ suspension or its suspending medium.

At $3 \mathrm{~h}$ after caffeine administration, plasma levels of both glucose and FFA were higher than those of control animals (results not detailed). Although the effect of caffeine was generally moderate, when the results of three experiments (undertaken in February, March and June I97I) were taken together, they were statistically significant for both glucose $(P<0.02)$ and FFA $(P<0.001)$. This characteristic response to caffeine (see Heim \& Ammon, 1968) is particularly noteworthy in view of the hypoglycemic effect exerted by the RNA diet. Thus, hypoglycemic responses to methylxanthines have also been occasionally recorded, probably due to the stimulatory effect of caffeine on insulin secretion by the pancreas (see Bellett et al. I968).

Short-term studies with $R N A$. A series of experiments similar to those with caffeine was undertaken, in which $48 \mathrm{~h}$-fasted rats were given a single meal ( $\mathrm{log}$ ) of either the control or the RNA-diet at the beginning of the dark period ( 19.00 hours). After various intervals (see Table 4 ), the animals were bled (cardiac puncture). In only a limited number of experiments was an additional group of animals bled immediately prior to refeeding.

The postprandial hyperglycemia was consistantly less pronounced in the rats given the RNA diet than in those given the control diet (Table 4). Composite statistical analysis showed that after both a short period $(5-9 \mathrm{~h})$ and a longer period (12-16 h) of refeeding, the effect was statistically significant $(\mathrm{P}<0.02$ and $P<0.01$ respectively). However, the plasma FFA response in different experiments was found to be very inconsistent and even contradictory.

After the completion of a series of short-term studies, a retrospective analysis was carried out to establish the origin of this variation. Plasma FFA levels in rats killed at the end of the $48 \mathrm{~h}$ fast period and during the early postprandial response to the control diet $(3.5-9 h)$ are both plotted in Fig. I $(a) v$. day of the year on which the experiment was performed (day I, January I). All experiments undertaken over an I8-month period which shared the same short-term design, including those in which the RNA diet was not used, are represented. Fasting and postprandial FFA levels both varied widely between experiments. If the low values obtained in late January and in May represent true minima, then they confirm a rhythm recognized previously by Barrett (I964) for normally fed rats. 
188

D. J. Heaf, D. G. Peers and J. I. Davies

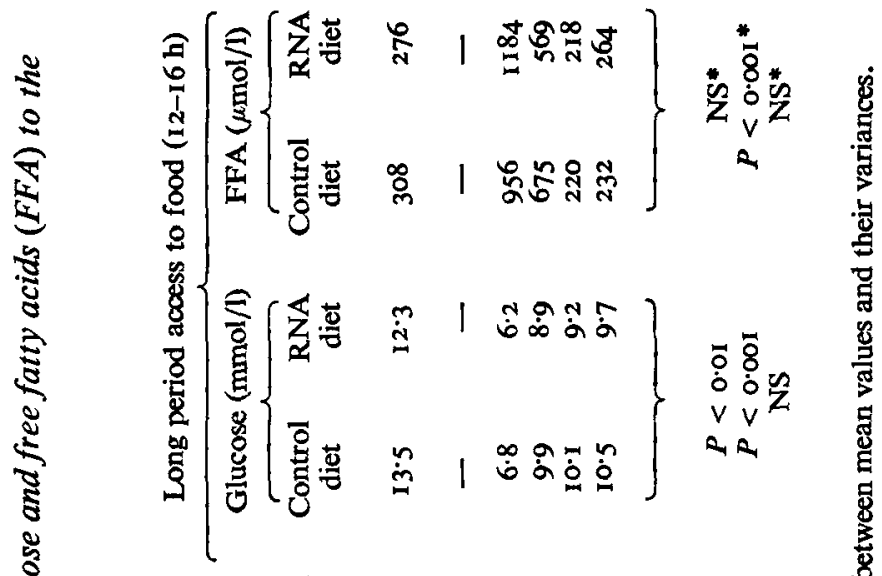

$\stackrel{3}{3}$

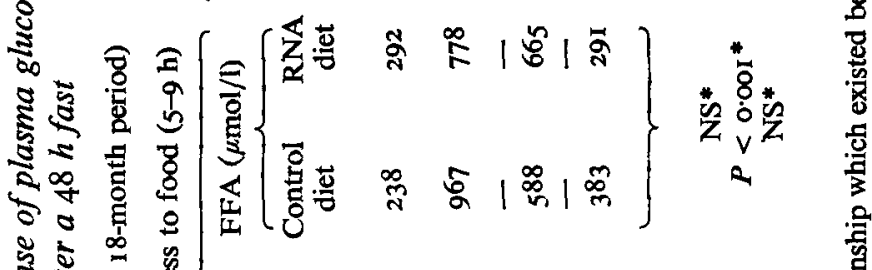

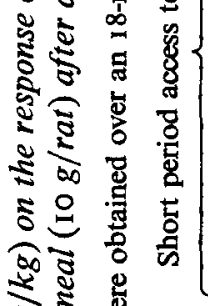

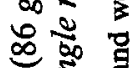

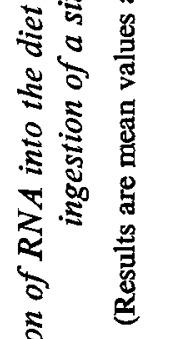

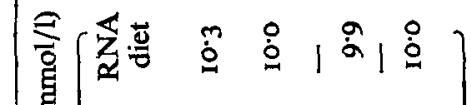

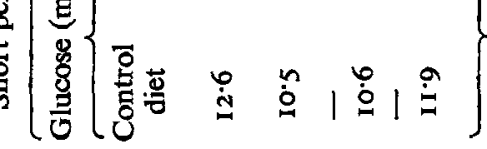

감

善

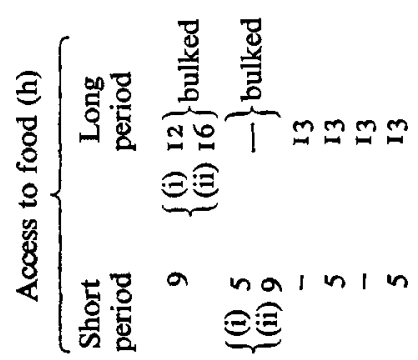

它迸

密

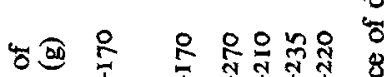

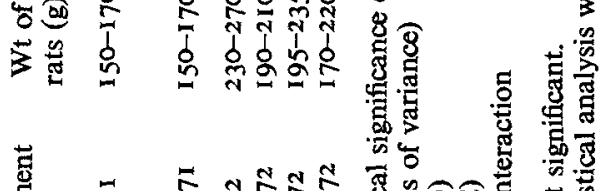

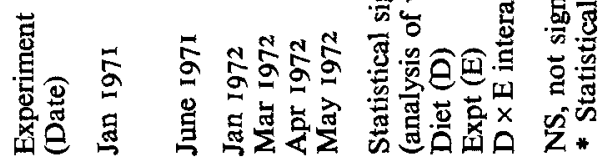



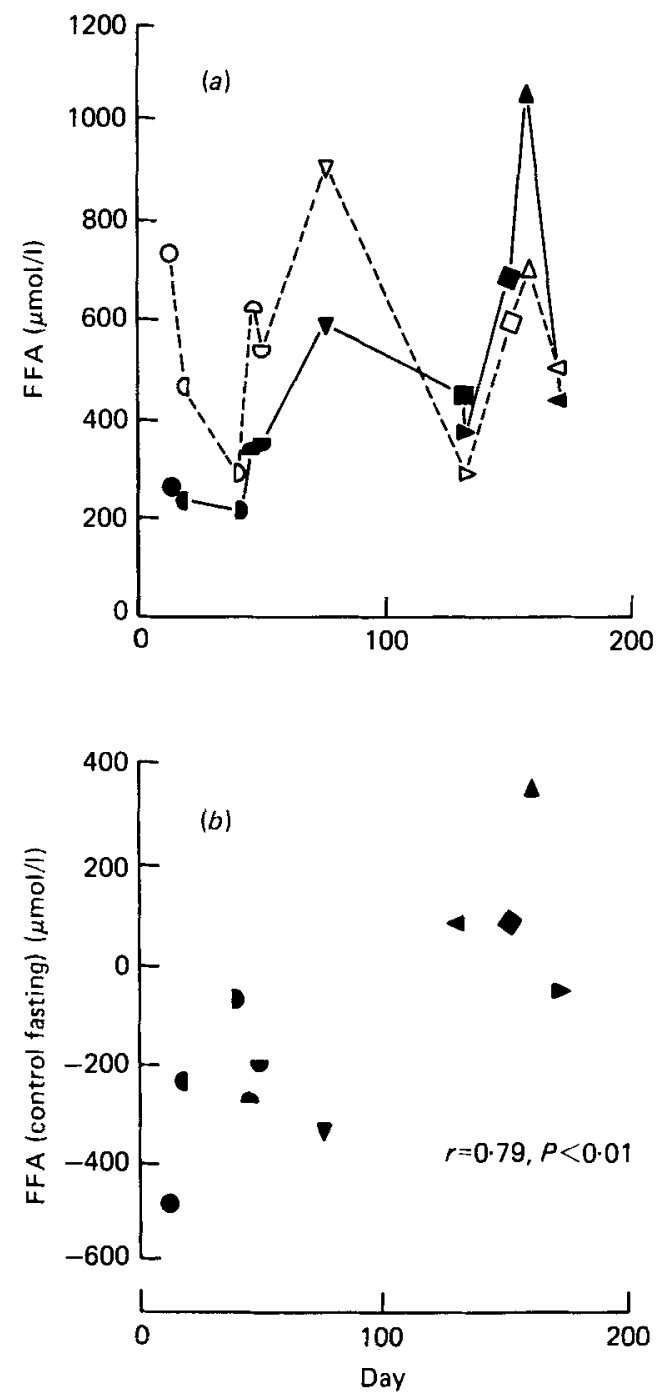

Fig. 1. Effect of season on plasma free fatty acids (FFA) $(\mu \mathrm{mol} / \mathrm{l})$. Two aspects of the behaviour of FFA are each plotted $v$. day no. (day 1 , January 1). (a) FFA in rats which had been fasted for $48 \mathrm{~h}$ (open symbols) and which had been briefly refed on the control diet (closed symbols), $(b)$ the response to feeding the $48 \mathrm{~h}$ fasted rats with the control diet (amount in excess of the value at the end of the $48 \mathrm{~h}$ fast ( $\triangle \mathrm{FFA}$ (control-fasting)). All experiments were of the short-term design (see pp. 184-I85) in which rats were given a single meal after a $48 \mathrm{~h}$ fast period. $(0,0) \mathrm{Jan} .197 \mathrm{I}$ (3 rats/treatment, I45-155 g, refed $3.5 \mathrm{~h}) ;(Q, 0)$ Jan. I97I (3 rats/treatment, $150-170 \mathrm{~g}$, refed $9 \mathrm{~h}$ ); (D, ) Feb. 1971 (6 rats/treatment, $160-200 \mathrm{~g}$, refed $4 \mathrm{~h}) ;(0,0)$ Feb. 1971 (3 rats $/$ treatment, $160-\mathrm{I} 80 \mathrm{~g}$, refed $3 \mathrm{~h}) ;(\sigma, \sigma)$ Feb. 197I (3 rats/treatment, 135-165 g, refed 2.5 h); (D) May I97I (6 rats/treatment, $260-280 \mathrm{~g}$, refed $6 \mathrm{~h}) ;(\diamond, \diamond)$ June $197 \mathrm{I}$ (3 rats/treatment, I60-180 g, refed $3 \mathrm{~h}) ;(\Delta, \Delta)$ June $197 \mathrm{I}$ (3 rats/treatment, $150-170 \mathrm{~g}$, refed $5 \mathrm{~h}) ;(\nabla, \nabla) \mathrm{Mar} .1972$ (5 rats/treatment, $190-210 \mathrm{~g}$, refed $5 \mathrm{~h}) ;(\triangleleft, 4)$ May 1972 (5 rats/treatment, $170-220 \mathrm{~g}$, refed $5 \mathrm{~h}) ;(\nabla, \nabla)$ June 1972 ( 3 rats/treatment, $200-230 \mathrm{~g}$, refed $5 \mathrm{~h}$ ). 

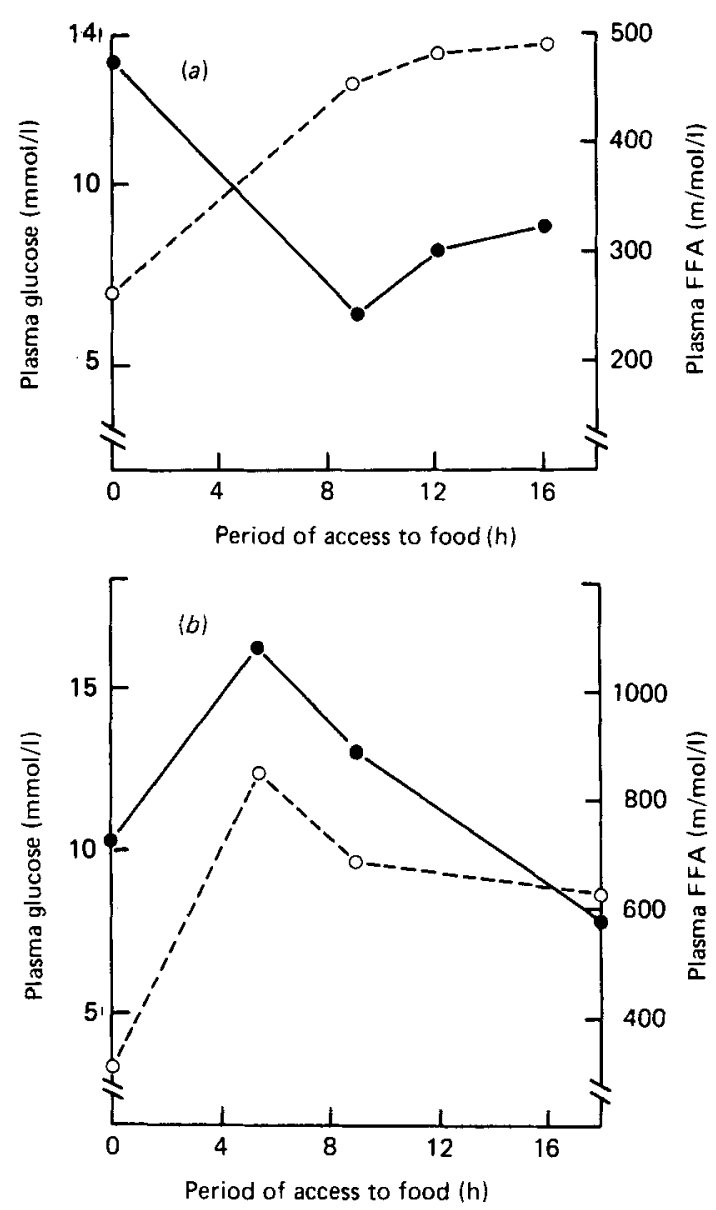

Fig. 2. Two different response patterns of glucose (O---O); free fatty acids (FFA) observed in blood plasma of $48 \mathrm{~h}$-fasted rats after access to $10 \mathrm{~g}$ balanced control diet: $(a)$, Jan 1971; (b), June 197I. For details of diet, see Table 1 .

However it appears that a rhythm of longer duration (probably 12 months) may influence the relationships between the two curves. Thus, when the results quoted in Fig. I $(a)$ are expressed as the change in mean FFA after refeeding and again plotted $v$. the day of the year, a statistically significant correlation $(P<0.0 \mathrm{I})$ is revealed over the period january to June (Fig. I $(b)$ ). The effect of food intake ranged from a lowering of FFA levels in the winter to an increase in the summer. None of these relationships was observed in the corresponding blood glucose values.

The two extreme patterns in the response of plasma FFA and glucose to refeeding which emerged in these short-term studies are illustrated in Fig. 2. In showing that both responses persist for many hours, these results indicate that the variation in blood sampling times in the experiments quoted in Fig. I $(b)$ is not likely to have been important.

Direct investigation of the relationship between the effect of the RNA diet and the behaviour of the control animals was severely limited in this retrospective analysis by the fact that in some experiments with the RNA diet either fasting FFA was not determined or the response to refeeding was not assessed within the first $9 \mathrm{~h}$. The results of all appropriately designed experiments undertaken over an 18 -month period are shown in Table 5 . It is apparent that the response to RNA (measured as either FFA (RNA-fasting) or FFA 


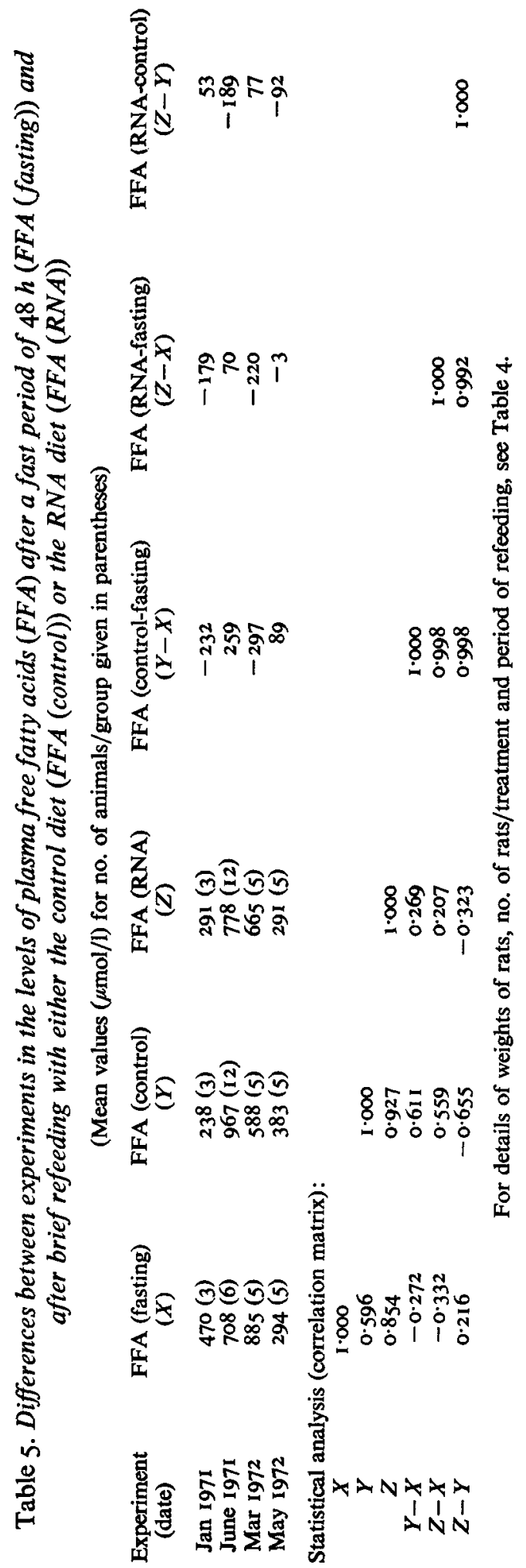




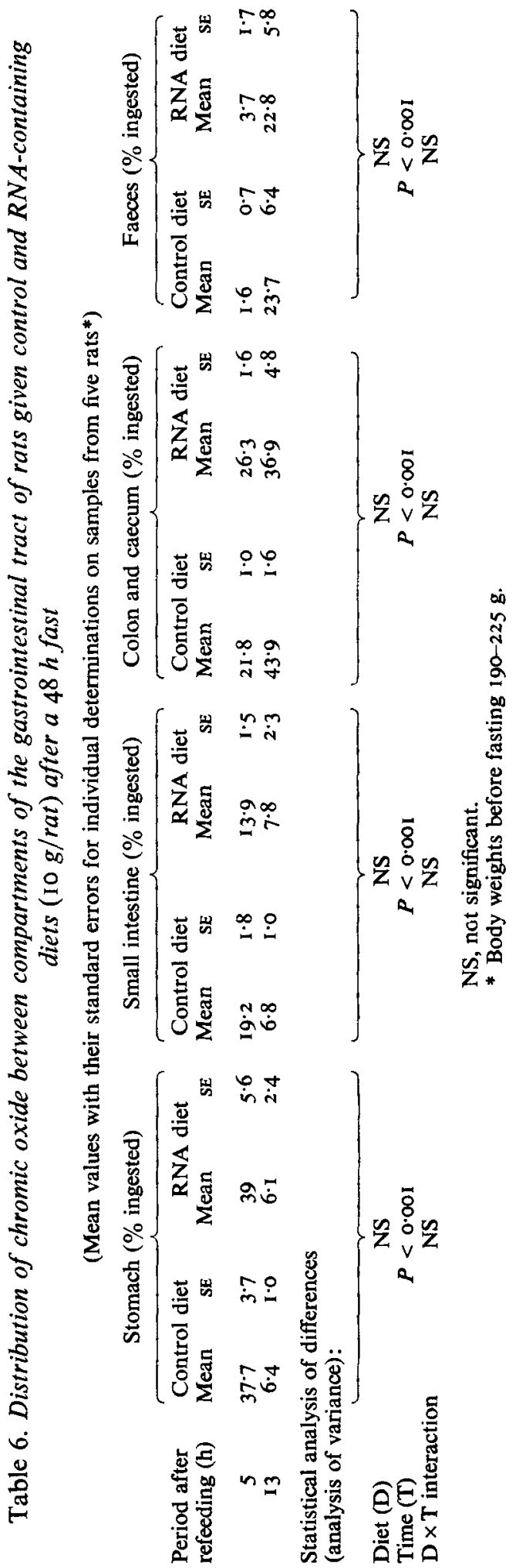


(RNA-control)) is not significantly correlated with either FFA (fasting) or FFA (control) but is strongly correlated with FFA (control-fasting). Despite the non-independence of FFA (RNA-control) and FFA (control-fasting), the behaviour of the latter as revealed in a separate analysis (Fig. I $(b)$ ), suggests that the FFA response to the RNA diet is influenced by the extended (probably I 2-month) rhythm of the animals. With respect to the control diet, the response to the RNA diet on plasma FFA ranged from an increase in the winter to a decrease in the summer. Thus, the results of the short-term experiments are reconciled with those of the $7 \mathrm{~d}$ trial (Table 3 ).

Experiments with $\mathrm{Cr}_{2} \mathrm{O}_{3}$ marker. Both short-term and long-term studies with $\mathrm{Cr}_{2} \mathrm{O}_{3}$ marker in the diet showed that the presence of RNA caused no significant disturbance in the flow of digesta along the gastrointestinal tract. The results of a typical short-term study, where $\mathrm{Cr}_{2} \mathrm{O}_{3}$ was measured in faeces and various parts of the alimentary tract at 5 and $13 \mathrm{~h}$ after feeding, are shown in Table 6. Since the housing of the animals might not entirely prevent coprophagy (see p. I 85) these values may not strictly measure the proportion of the meal which had passed through the body at the time of sampling. In a long-term study in which rats were allowed free access to either RNA or control diets for up to $20 \mathrm{~d}$, no disturbance in digesta flow was caused by RNA in the diet (Heaf \& Davies, 1976).

\section{DISCUSSION}

Monitoring plasma FFA and glucose concentrations in safety-testing of potential food constituents lacking acute toxicity is justified because they are criteria which may assist in the prediction of longer-term detrimental effects such as ischaemic heart disease and thrombosis (Steinberg, 1966; Carlson \& Olsson, 1974; Spector \& Hoak, 1975). Although their sensitivity to disturbances of metabolism is one of their most useful features, it also creates difficulties in that they respond to environmental factors which are difficult to accommodate (Barrett, I964). In our studies, efforts were made to minimize psychological stress by minimizing the handling of animals other than in their routine management and by carefully regulating interference with cages. As a result, in individual experiments, the variance amongst replicated blood measurements was confined to a narrow range. Nevertheless the somewhat increased blood glucose levels detected in rats killed by diethyl ether exposure as compared with those killed by the standard decapitation technique emphasizes the importance of providing adequate controls.

Since RNA had no detectable effect on palatability, it was administered by incorporation into the diet. The method used was to substitute the RNA preparation for $100 \mathrm{~g}$ of the $150 \mathrm{~g}$ cellulose $/ \mathrm{kg}$ in the control diet. Analytically, cellulose is a fibre. However, it is now becoming clear that the physiological effects of different fibres vary widely (Wells \& Ershoff, 1961; Tsai et al. 1976) and since microcrystalline cellulose is amongst the most inert in this respect, it seems a reasonable choice of agent against which to compare RNA. The alternative of supplementing the control diet with RNA may equally create ambiguities because of the increased physical bulk of the test diet compared with the control (O'Hea et al. I974; Kritchevsky et al. 1974; Steffens, 1976).

RNA and cellulose differ in that the digestion of the former in the gut of the rat is fairly complete, as indicated by experiments with radiolabelled substrates (Prończuk et al. 1972) and urinary inorganic phosphate analyses (Heaf \& Davies, 1976), whereas that of cellulose is minimal (Southgate, 1973). However, absorbed RNA-derived purines are largely eliminated as allantoin (Roll et al. 1949; Barnard, 1969) and even though the accompaning pyrimidines are liable to complete degradation (Fink et al. 1952; Barnard, 1969), extensive uracil excretion occurs under the conditions of these experiments (Heaf \& Davies, 1976). The only component which is well-utilised, therefore. is ribose; the energy contribution of 
which to the RNA diet is approximately $6.5 \%$ of that of the starch and sucrose present. No evidence was found that the difference in cellulose content of the RNA and control diets affected the passage of food along the gastrointestinal tract (cf. Eastwood et al. 1973).

Our results show that the RNA diet lowered blood glucose levels slightly but consistently compared with the control diet. Although insulin-like activities have been observed in RNA in vitro (Dole, 1962), its mode of action in the intact animal remains uncertain. Influences upon pentose sugar metabolism following RNA ingestion appear to be insufficient to affect the level of glucose in the blood (Heaf \& Davies, 1976), despite the known hypoglycaemic effect of ribose (Segal et al. 1957; Sloviter et al. 1964; Hetenyi \& Ishiwata, 1968).

In blood, the substance most affected by RNA ingestion is uracil (Heaf \& Davies, 1976). The recorded effects on blood constituents of administering this base include a brief hyperglycaemia in the rabbit (Hashimoto \& Chuman, 1963).

A report by Haugaard et al. (1977), which appeared during the preparation of this paper, provides the most plausible clue to the hypoglycaemic effect of RNA. They showed that in rat diaphragm incubated in a medium containing uridine, intracellular levels of uridine-5triphosphate and uridine diphosphate glucose were increased, and that this led to an enhancement of glycogen synthesis. The interaction observed between uridine and insulin indicated that the nucleoside might operate in vivo either to enhance the effectiveness of the hormone action or to exert an independent insulin-like effect. In the experiments described here, the RNA diet slightly increased uridine levels in the blood (Heaf \& Davies, 1976). It is not clear, however, whether this is as relevant as the much greater increase which occurred in concentration of uracil, since the salvage of pyrimidine bases in a number of tissues appears to be limited largely by the availability of the substrates (Canellakis, I957; Cooper et al. 1972).

Normally, after the ingestion of a meal, the subsequent increase in blood glucose concentration and increased availability of glucose for FFA esterification in adipose tissue, leads to a simultaneous fall in plasma FFA levels (Dole, 1956; Randle et al. I963). The effect of the RNA diet on plasma FFA did not simply reflect the changes observed in plasma glucose, but varied in a way which appeared to be related to the state of the animal at the time. The dependence of the response on the physiological state of the animals might suggest that the interference with metabolism caused by RNA is relatively weak. However, it is also possible that a conflict between two opposing effects is involved which are individually more potent.

Simultaneous increases in both FFA and glucose, such as were observed here, are commonly associated with stressful situations (Havel \& Goldfien, 1959). Furthermore, there are a number of reports which indicate that differences in sympathetic nervous activity are responsible for variations in the effects of drugs on plasma FFA. Garattini \& Bizzi (1966) showed that the $\beta$-adrenergic blocker propranolol enhanced or diminished rat plasma FFA in different experiments and that the direction of the effect was closely related to the plasma FFA of control animals. Similarly, we interpret the variations in the effect of RNA to changes in sympathetic tone. In our experiments, however, it appears that the plasma FFA response to the RNA diet was related not to either control or fasting values but to the change in plasma FFA concentrations following limited refeeding with the control diet (cf. Trenchard, 1975). The sympathetic nervous activity may be associated specifically with arousal rather than generally with stress. Since the arousal is greater in the summer months and reveals itself in food-deprived animals, it is tempting to speculate that it is related to the seasonal cycles of aggression associated with the dispersal of rodent populations in the wild (Krebs \& Myers, I974).

It appears to be necessary to postulate the existence of an external synchronizer of the observed seasonal effect since endogenous age-related changes in the animals were 


\section{Dietary RNA and energy homoeostasis}

eliminated by importing new groups of rats in a narrow weight range for each experiment. No such synchronizer was identified. In many previous studies, the powerful effect of photo-period has appeared to be a likely candidate. These include seasonal effect on plasma FFA (Barrett, 1964), serum cholesterol (Thorp \& Waring, 1962; Edgren, 1963) and insulin sensitivity in the perfused heart (Young, 1965). Variation in photo-period was eliminated in the present study; the possibility of exposure to natural lighting being confined entirely to the brief period of shipment.

One possible synchronizer or inducer of metabolic rhythms which was not fully controlled was the laboratory temperature. This was maintained at $2 \mathrm{I}^{\circ}$ in the winter but no facilities were available to prevent it from increasing in response to outdoor temperatures in the summer. It is conceivable, therefore, that raised environmental temperature may have had a similarly stressful effect. This explanation seems improbable in view of the finding of Jouanneteau et al. (1975) showing that the effect of temperature on a number of measurements of lipid metabolism in the rat was itself seasonally dependent. Again, in experiments with standardized lighting and temperature, seasonal variations have been detected in the glycogen content of diaphragm muscle (Pessacq \& Gagliardino, 1975) and in a number of blood measurements (Cuendat et al. 1975) in two different strains of mice.

Since susceptibility to seasonal influences may be a characteristic of lipid metabolism in the rat, it is interesting that a number of such effects have been detected in adipose tissue (Boright et al. 1962; Blackard \& Cameron, 1967).

Our findings emphasize the caution necessary in extrapolating from the results of food and drug safety-testing experiments performed under a restricted range of environmental conditions. An attempt was made to broaden the range of these conditions by deliberately stressing the animals. The response to RNA diet was compared in rats housed at normal laboratory temperature and rats in which the tone of the sympathetic nervous system was deliberately raised by exposure to a $4^{\circ}$ environmental temperature (cf. Gilgen et al. 1962). Although indications of diet-temperature interaction were revealed, they were not adequately resolved in these experiments. One of the difficulties with the design of these experiments is that cold-exposure increases the demand for the energy provided by blood glucose and fatty acids in order to combat heat loss.

Although from these studies it appears that RNA in the diet has a mild hypoglycaemic effect, the inconsistent response in FFA prevents a general comment being made on the long-term implications of feeding diets containing high levels of RNA. A great deal of insight would be obtained from a knowledge of the relationship between the observed effects and the level of RNA administration. However, it has been pointed out elsewhere (Heaf \& Davies, 1976) that the level of RNA in the test diet used is approximately equivalent to that of a diet containing $30 \%$ protein, where the protein is derived entirely from fastgrowing bacteria (bacterial SCP).

We wish to thank Mr A. Vardy, School of Plant Biology, Bangor, for advice on the statistical analysis of our experimental results.

Some financial assistance towards this study was provided by the Rank Research Centre, High Wycombe, Bucks. D.J.H. was in receipt of a Postgraduate Award from the Ministry of Agriculture and Fisheries, London.

\section{REFERENCES}

Barnard, E. A. (1969). Nature, Lond. 221, 340.

Barrett, A. M. (1964). Br. J. Pharmac. 22, 577.

Bellet, S., Sandberg, H., Feinberg, L. \& Decastro, O. (1968). Coffein und anders Methylxanthine, p. 181 [F. Heim and H. P. T. Ammon, editors]. Stuttgart: Schattaner Verlag. 
Bizzi, A. \& Garattini, S. (1966). In Methods of Drug Evaluation, p. 68 [P. Mantegazza and F. Piccinini, editors]. Amsterdam, N. Holland.

Blackard, W. G. \& Cameron, T. (1967). Metabolism 16, 91.

Boright, H. A., Engel, F. L., Lebovitz, H. E., Kostyo, J. L. \& White, J. E. (I962). Biochem. J. 83, 95.

Bowering, J., Calloway, H., Margen, S. \& Kaufmann, N. A. (1970). J. Nutr. 100, 249.

Canellakis, E. S. (1957). J. biol. Chem. 227, 701 .

Carlson, L. A. \& Olsson, A. G. (1974). In Modern trends in cardiology, p. 405 [M. F. Oliver, editor]. London: Butterworths.

Cooper, G. M., Dunning, W. F. \& Greer, S. (1972). Cancer Res. 32, 390.

Cuendat, G. S., Loten, E. G., Cameron, D. P., Renold, A. E. \& Marliss, E. B. (1975). Am. J. Physiol. 228, 276.

Cuthbertson, W. F. S. (1957). Proc. Nutr. Soc. 16, 70.

Dole, V. P. (1956). J. clin. Invest. 35 , I50.

Dole, V. P. (1962). J. biol. Chem. 237, 2758.

Eastwood, M. A., Kirkpatrick, J. R., Mitchell, W. D., Bone, A. \& Hamilton, T. (1973). Br. med. J. iv, 392.

Edgren, R. A. (1963). J. Atherscler. Res. 3, 206.

Fink, K., Henderson, R. B. \& Fink, R. M. (1952). J. biol. Chem. 197, 441.

Friedman, L., Glaser, O. G., Brown, N. L. \& Pariser, E. R. (1971). Toxic. appl. Pharmac. x8, 239.

Garattini, S. \& Bizzi, A. L. (1966). Pharmac. Rev. r8, 243.

Gilgen, A., Maickel, R. P., Nikodijevic, O. \& Brodie, B. B. (1962). Life. Sci. 12, 709.

Hashimoto, S. \& Chuman, Y. (I963). J. Vitam. 9, 227.

Haugaard, E. S., Frantz, K. B. \& Haugaard, N. (1977). Proc Natl. Acad. Sci. 74, 2339.

Havel, R. J. \& Goldfien, A. (1959). J. Lipid Res. I, 102.

Heaf, D. J. \& Davies, J. I. (1976). Br. J. Nutr. 36, 38 I.

Heim, F. \& Ammon, H. P. T. (1968). In Coffein und andere Methylxanthine [editors]. Stuttgart: Schattauer Verlag.

Hetenyi, G. \& Ishiwata, K. (1968). Am. J. Physiol. 214, 1333.

Jouanneteau, J., Favier, R. \& Perez, G. (1975). Compt. Rend. Soc. Biol. 6, 1526.

Kihlberg, R. (1972). A. Rev. Microbiol, 26, 427.

Krebs, C. J, \& Myers, J. H. (1974). Adv. Ecol. Res. 8. 267.

Kritchevsky, D., Tepper, S. A. \& Story, J. A. (1974). Nutr. Rep. int. 9, 30 I.

Kutscher, C. L. (1971). Physiol. Behaviour 7, 283.

Layne, E. (1957). Meth. Enzym. 3, 450.

O'Hea, E. K., Aldis, E. A., Skidmore, G. B-, Smith, B. H., Stevenson, S., Strongithram, D. \& Stuart, G. C. E. (1974). Comp. Biochem. Physiol. 48A, 21 .

Peers, D. G. (1974). Effects of nucleic acid derivatives on carbohydrate metabolism in mammals. Ph D Thesis, University of Wales.

Peers, D. G., Heaf, D. J. \& Davies, J. I. (1973). Proc. FEBS Special Meeting on Industrial Aspects of Biochemistry, Dublin, Abstr. I 6 .

Pessacq, M. T. \& Gagliardino, J. J. (1975). Metabolism 24, 737.

Prończuk, A., Lubszyński, S. \& Bartnik, J. (1972). Nutr. Abstr. Revs. 42, 951, Abstr. 5745.

Randle, P. J., Garland, P. B., Hales, C. N. \& Newsholme, E. A. (1963). Lancet i, 785.

Roll, P. M., Brown, G. B., Di Carlo, F. J. \& Schultz, A. S. (1949). J. biol. Chem. r8o, 333.

Segal, S., Foley, J. \& Wyngaarden, J. B. (1957). Proc. Soc. expt. Biol. Med. 95, 55I.

Sloviter, H. A., Iteka, M. \& Sakata, K. (1964). Am. J. Physiol. 207, 407.

Snedecor, G. W. \& Cochran, W. G. (1967). Statistical Methods, 6th ed. pp. 329, 472. Ames Iowa: Iowa State University Press.

Southgate, D. A. T. (1973). Proc. Nutr. Soc. 32, 131.

Spector, A. A. \& Hoak, J. C. (1975). Science, N.Y. r9o, 490.

Steffens, A. B. (1976). Am. J. Physiol. 230, I4I I.

Steinberg, D. (1966). Pharmac. Rev. 18, 217.

Thomas, A. J. (1970). In Automation, Mechanisation and Data Handling in Microbiology, p. 109 [A. Baillie \&

R. J. Gilbert, editors]. London: Academic Press.

Thorp, J. M. \& Waring, W. S. (I962). Nature, Lond. 194, 948.

Trenchard, P. M. (1975). Clinica chim. Acta 65, 139.

Tsai, A. C., Elias, J., Kelley, J. J., Lin, R.-S. C. \& Robson, J.-R. K. (I976), J. Nutr. 1o6, 118.

Waslien, C. I., Calloway, D. H. \& Margen, S. (I968). Am. J. clin. Nutr. $21,892$.

Wells, A. F. \& Ershoff, B. H. (196r). J. Nutr. 74, 87.

Young, D. A. B. (1965). J. Physiol, Lond. 178, 530. 